\title{
Does the Gut Microbiota Influence Immunity and Inflammation in Multiple Sclerosis Pathophysiology?
}

\author{
Monika Adamczyk-Sowa, Aldona Medrek, Paulina Madej, \\ Wirginia Michlicka, and Pawel Dobrakowski \\ Department of Neurology in Zabrze, Medical University of Silesia, ul. 3-go Maja 13-15, 41-800 Zabrze, Poland \\ Correspondence should be addressed to Aldona Medrek; aldona767@gmail.com
}

Received 20 September 2016; Revised 31 December 2016; Accepted 2 February 2017; Published 20 February 2017

Academic Editor: Ilian Radichev

Copyright (c) 2017 Monika Adamczyk-Sowa et al. This is an open access article distributed under the Creative Commons Attribution License, which permits unrestricted use, distribution, and reproduction in any medium, provided the original work is properly cited.

\begin{abstract}
Aim. Evaluation of the impact of gut microflora on the pathophysiology of MS. Results. The etiopathogenesis of MS is not fully known. Gut microbiota may be of a great importance in the pathogenesis of MS, since recent findings suggest that substitutions of certain microbial population in the gut can lead to proinflammatory state, which can lead to MS in humans. In contrast, other commensal bacteria and their antigenic products may protect against inflammation within the central nervous system. The type of intestinal flora is affected by antibiotics, stress, or diet. The effects on MS through the intestinal microflora can also be achieved by antibiotic therapy and Lactobacillus. EAE, as an animal model of MS, indicates a strong influence of the gut microbiota on the immune system and shows that disturbances in gut physiology may contribute to the development of MS. Conclusions. The relationship between the central nervous system, the immune system, and the gut microbiota relates to the influence of microorganisms in the development of MS. A possible interaction between gut microbiota and the immune system can be perceived through regulation by the endocannabinoid system. It may offer an opportunity to understand the interaction comprised in the gut-immune-brain axis.
\end{abstract}

\section{Introduction}

1.1. Definition of Multiple Sclerosis. Multiple sclerosis (MS) is a progressive disease of the central nervous system (CNS) characterized by the presence of lesions in the brain and the spinal cord [1]. Nylander and Hafler [2] demonstrated that the inflammatory factor in MS contains CD4 and CD8 T cells, $\mathrm{B}$ cells, and activated monocytes that result in the degradation of the myelin sheath surrounding nerves. Traditionally, inflammatory demyelination has been considered the primary form of the pathogenesis in MS.

Although the etiology of MS remains unclear, several hypotheses suggest that autoimmunity plays a major role in the development of the disease. The most widely supported view is that MS is a CD4+ T cell-driven autoimmune disorder [3]. In MS lesions, astrocytes play a paradoxical role during disease development [4]. Experimental data show that astrocytes not only mediate inflammation but also diminish the detrimental effects of proinflammatory factors. Activated astrocytes secrete compounds including reactive oxygen and nitrogen species [5], which have toxic effects on neurons. Oxidative stress is a key factor in the pathogenesis of MS. Activated macrophages and microglia in the CNS produce reactive oxygen species (ROS) and reactive nitrogen species (RNS) and secrete cytokines (tumor necrosis factor (TNF), interleukin-1 (IL-1), and interleukin-6 (IL-6)) and chemokines (macrophage inflammatory protein (MIP-1), monocyte chemoattractant protein (MCP-1), and interferon-gamma$($ IFN- $\gamma$-) induced protein (IP-10)). Neurodegeneration during MS may result from chronic oxidative stress and excitotoxicity [6].

Recent clinical and experimental studies indicate that MS arises from a negative interaction between genetics and environmental factors $[7,8]$. Multiple sclerosis has a complex genetic component including the haplotype HLA-DR15 and over 100 of other types of minor risk alleles involved in the 
immune response. Additionally, several environmental and lifestyle factors contribute to the onset of MS, including latitude, deficiency of vitamin D3, obesity early in life, cigarette smoking, and the Epstein-Barr virus (EBV). Hedström et al. [9] and Alotaibi attempted to find a relationship between the active form of vitamin D3, 1,25-OH D3, and the major histocompatibility complex (MHC) HLA-DRB $1 * 15$ allele, which is linked to an increased risk of developing MS [10]. The study results of Hedström and Alotaibi [11] suggest that HLA$\mathrm{DRB} 1 * 15$ only contributes to the risk of disease when susceptible individuals are deficient in vitamin $\mathrm{D}$.

In the 1970s, a relationship between the $6 \mathrm{p} 21$ region of the HLA gene and MS risk was discovered. In the following three decades, this region was only considered a genetic risk factor that increased susceptibility to MS. It was not until the introduction of genome-wide association studies (GWAS) that new genetic risk factors were found (the International Multiple Sclerosis Genetics Consortium). There is considerable variability in HLA genes in patients with MS. Research in Europe and the United States has revealed the existence of three HLAs that occur more frequently in MS compared to the general population. Further research in the US has shown that MS is more likely to occur in individuals who possess more than one of these HLAs. It can be assumed that the HLA system correlates with the course of the disease [11]. There are at least two genes, apart from HLA-DRA, on which single-nucleotide polymorphisms (SNPs) can occur, which may increase susceptibility to MS: the IL2R gene (an encoding subunit of the IL-2) and IL7RA gene (a subunit of IL-7) (the International Multiple Sclerosis Genetics Consortium). Furthermore, the risk of MS may be altered by polymorphic variants of ALCAM, CD6, CD80, CD86, and CD40 genes. Lastly, there may be sex-related genetic factors that contribute to the risk of MS. Reduced levels of CD6 mRNA in men and a reduced expression of the CD40L gene in women may increase the risk of developing MS (Pender).

Multiple human epidemiological studies have revealed the effects of environmental factors on the prevalence of MS [11] and demonstrated that viral infections, lack of sun exposure, vitamin D deficiency, active or passive smoking, season of birth, obesity, vitamin A deficiency, dietary habits (especially high levels of salt and fat), stress, and the intestinal microflora play a significant role in the initiation of the disease. EBV is a widely recognized risk factor. A seroepidemiological study of MS found that nearly $100 \%$ of the patients were infected with EBV [13]. If EBV infection occurs in late childhood, it is considered the largest risk factor for the development of MS. There is a strong EBV-specific CD8+ response in the blood during the onset of MS; the intensity of the response decreases during the course of the illness $[14,15]$.

Neuropathological studies support roles for the human herpes virus (HHV-6) and human endogenous retroviruses (HTLV-1/2, HIV-1/2) as risk factors for the development of MS. Herpes viruses can reactivate or cause de novo infections, leading to neurological disabilities [16]. Other risk factors include lack of sun exposure and deficiency of vitamin D [17]. Spelman et al. [18] demonstrated latitude-dependent lag between seasonal ultraviolet radiation (UVR) and relapse probability, which showed that the probability of a relapse increases in MS patients living at latitudes further from the equator. Additionally, MS patients living at further latitudes have significantly lower levels of vitamin $\mathrm{D}$ in all seasons of the year. These patients reach a low threshold level of $25(\mathrm{OH}) \mathrm{D}$, long immunomodulatory effect sooner after the winter solstice compared to people residing at more equatorial latitudes. Low levels of vitamin D have been observed in other neurological diseases, including Alzheimer's disease, Parkinson's disease, and stroke [19]. A meta-analysis showed that individuals born in autumn have a high risk of MS, based on their exposure to UV light and vitamin D levels [20]. Studies show that the risk of the disease decreases with diets low in salt and fat and with the use of essential oils from Pterodon emarginatus, a Brazilian legume [21].

Symptoms of MS include cognitive deficits, impaired information processing, and long-term memory deficits [22, 23]. Clinical symptoms are muscle weakness, blurred vision, dizziness, and fatigue [2].

\section{Main Text}

2.1. The Definition of Gut Flora. Gut microflora is the population of microorganisms living in the human gut. Microflora can be loosely divided into harmless, beneficial, or pathogenic forms. Intestinal microflora develops within the first few years of life and then remains largely stable. There are an estimated $1000+$ different types of intestinal flora (Table 1). The main factors that influence the composition of the intestinal flora after birth are the duration of pregnancy and the method of delivery (natural childbirth or caesarean section) [24]. Premature birth is associated with the presence of Staphylococcus. Children born vaginally have a higher incidence of Lactobacillus and Prevotella, while children born by caesarean section have a higher incidence of Staphylococcus, Corynebacterium, and Propionibacterium [25]. Facultative anaerobic bacteria such as Escherichia coli and other coliform bacteria are the first colonizers of the intestine in infants. In the first year of life, the intestine is colonized by Bacteroides, Clostridium, Ruminococcus, and Bifidobacteria [26]. Breastfeeding promotes Bifidobacteria and Lactobacillus proliferation. The intestinal microflora of a 3-year-old child is identical to that of an adult [27, 28]. Mariat et al. [29] suggested that the changes in the composition of the intestinal flora might result in the dysfunction of the immune system in elderly adults. Collins et al. [30] reported that the adult intestinal flora is mainly composed of four main clusters: Firmicutes, Bacteroidetes, Actinobacteria, and Proteobacteria. Tuohy et al. [31] reported that the intestinal flora can be divided into three groups, including health benefits, bacteria of the genera Bifidobacterium and Lactobacillus, and opportunistic microorganisms $[32,33]$.

2.2. GALT System. The gut-associated lymphoid tissue (GALT) is the largest immune system in the body. Intestinal bacteria act through the lymphatic system, which is associated with the digestive tract, that is, the GALT system. The GALT consists of organized cellular complexes (Peyer's patches and solitary lymphoid follicles) and dispersed cells 
TABLE 1: The composition of human intestinal flora.

\begin{tabular}{|c|c|c|c|c|c|}
\hline $\begin{array}{l}\text { The name of the } \\
\text { bacteria }\end{array}$ & $\begin{array}{l}\text { The amount of } \\
\text { bacteria }\end{array}$ & Age of occurrence & $\begin{array}{c}\text { The origin of the } \\
\text { bacteria }\end{array}$ & Influence & Role \\
\hline Staphylococcus & $<10^{5} \mathrm{CFU} \mathrm{ml} l^{-1}$ & Acute prematurity & Caesarean section & Pathogenic & $\begin{array}{l}\text { Unfolding mucin whose } \\
\text { parts are used as food for } \\
\text { the body. } \\
\text { One of the first pathogens } \\
\text { inhabiting the intestinal } \\
\text { flora [Palmer et al., 2007] }\end{array}$ \\
\hline Actinobacteria & $10^{4} \mathrm{CFU} \mathrm{ml}^{-1}$ & $\begin{array}{c}\text { From the first years } \\
\text { of life }\end{array}$ & With food & Beneficial & $\begin{array}{l}\text { Coordination of the } \\
\text { immune system } \\
\text { Stimulation of } \\
\text { gastrointestinal } \\
\text { motilityProduction of } \\
\text { bioactive compounds, } \\
\text { including antibacterial, } \\
\text { antifungal, and } \\
\text { anthelmintic drugs as well } \\
\text { as antitumor and antiviral } \\
\text { drugs, for example, } \\
\text { streptomycin and } \\
\text { kanamycin [Kumar et al., } \\
\text { 2010] }\end{array}$ \\
\hline Bacteroides & $\begin{array}{l}10^{10} \text { to } 10^{11} \text { per } \\
1 \mathrm{~g} \text { of the content }\end{array}$ & From the age of 3 & $\begin{array}{l}\text { With a decreasing } \\
\text { amount of oxygen } \\
\text { in the intestine } \\
\text { There are } \\
\text { obligatory } \\
\text { anaerobes }\end{array}$ & $\begin{array}{l}\text { Endogenous } \\
\text { bacteria due to } \\
\text { infection }\end{array}$ & $\begin{array}{l}\text { Production of vitamins B7, } \\
\text { B2, and C Inhibition of the } \\
\text { growth of pathogens and } \\
\text { harmful bacteria [Round et } \\
\text { al., 2011] } \\
\text { They stimulate the } \\
\text { formation of iTreg [Round } \\
\text { et al., 2011] }\end{array}$ \\
\hline Clostridium & $<10^{5} \mathrm{CFU} \mathrm{ml}^{-1}$ & $\begin{array}{l}\text { The largest number } \\
\text { in the adulthood }\end{array}$ & $\begin{array}{l}\text { With a decreasing } \\
\text { amount of oxygen } \\
\text { in the intestine } \\
\text { There are } \\
\text { obligatory } \\
\text { anaerobes }\end{array}$ & Pathogenic & $\begin{array}{l}\text { They stimulate the } \\
\text { formation of Treg relevant } \\
\text { in reducing the pathology } \\
\text { dependent on Th2 cells in } \\
\text { the mucous membranes of } \\
\text { the respiratory system } \\
\text { [Atarashi et al., } \\
\text { 2011] [Josefowicz et al., } \\
\text { 2012] }\end{array}$ \\
\hline Ruminococcus & $\begin{array}{c}10^{5}- \\
10^{6} \mathrm{CFU} \mathrm{ml}^{-1}\end{array}$ & From the age of 3 & Natural childbirth & Beneficial & $\begin{array}{l}\text { Unfolding mucin, which } \\
\text { helps the intestine absorb } \\
\text { the fragments used as food } \\
\text { for the body [Præsteng et } \\
\text { al., 2013] }\end{array}$ \\
\hline Bifidobacteria & $\begin{array}{c}10^{10} \text { to } \\
10^{11} \mathrm{CFU} \mathrm{ml}^{-1}\end{array}$ & $\begin{array}{c}\text { From the first years } \\
\text { of life if the child is } \\
\text { breastfed }\end{array}$ & Mother's milk & Beneficial & $\begin{array}{l}\text { They form a natural } \\
\text { protective barrier against } \\
\text { pathogens by producing } \\
\text { bacteriocin and organic } \\
\text { acids. } \\
\text { Stimulation of } \\
\text { gastrointestinal motility } \\
\text { [Bottacini et al., 2014] }\end{array}$ \\
\hline Veillonella & $10^{5} \mathrm{CFU} \mathrm{ml}^{-1}$ & $\begin{array}{c}\text { From the first years } \\
\text { of life }\end{array}$ & With food & Pathogenic & $\begin{array}{l}\text { Coordination of the } \\
\text { immune system } \\
\text { Stimulation of } \\
\text { gastrointestinal motility } \\
\text { This increases the } \\
\text { concentrations of IL-8, } \\
\text { IL-6, IL-10, and TNF- } \alpha \\
\text { [van den Bogert et al., 2014] }\end{array}$ \\
\hline
\end{tabular}


TABLE 1: Continued.

\begin{tabular}{|c|c|c|c|c|c|}
\hline $\begin{array}{l}\text { The name of the } \\
\text { bacteria }\end{array}$ & $\begin{array}{c}\text { The amount of } \\
\text { bacteria }\end{array}$ & Age of occurrence & $\begin{array}{c}\text { The origin of the } \\
\text { bacteria }\end{array}$ & Influence & Role \\
\hline Prevotella & $\begin{array}{c}10^{6}- \\
10^{7} \mathrm{CFU} \mathrm{ml}^{-1}\end{array}$ & From birth & Natural childbirth & Pathogenic & $\begin{array}{l}\text { Production of vitamin B1 } \\
\text { and folic acid } \\
\text { Inhibiting the growth of } \\
\text { pathogens and harmful } \\
\text { bacteria [Koskey et al., } \\
\text { 2014] }\end{array}$ \\
\hline Streptococcus & $<10^{5} \mathrm{CFU} \mathrm{ml}^{-1}$ & From birth & $\begin{array}{l}\text { The first organisms } \\
\text { that colonize the } \\
\text { intestine }\end{array}$ & Pathogenic & $\begin{array}{l}\text { Stimulation of the immune } \\
\text { system by the ability of } \\
\text { adhesion to the bowel } \\
\text { mucosa [Wang et al., 2014] }\end{array}$ \\
\hline Lactobacillus & $\begin{array}{l}10^{8} \text { to } 10^{10} \text { per } \\
1 \mathrm{~g} \text { of the content }\end{array}$ & $\begin{array}{l}\text { From the first years } \\
\text { of life if the child is } \\
\text { breastfed }\end{array}$ & Natural childbirth & Beneficial & $\begin{array}{l}\text { Create natural barriers to } \\
\text { the growth of pathogenic } \\
\text { bacteria by production of } \\
\text { bacteriocin and organic } \\
\text { acids [Bottacini et al., 2014] }\end{array}$ \\
\hline Escherichia coli & $>10^{6} \mathrm{CFU} \mathrm{ml}^{-1}$ & $\begin{array}{c}\text { The first few hours } \\
\text { of life }\end{array}$ & $\begin{array}{l}\text { With a decreasing } \\
\text { amount of oxygen in } \\
\text { the intestine } \\
\text { There are obligatory } \\
\text { anaerobes }\end{array}$ & Pathogenic & $\begin{array}{l}\text { Production of vitamins B } \\
\text { and } \mathrm{K} \\
\text { It produces fecal enzymes } \\
\text { and synthesized } \\
\text { carcinogens [Grudniak et } \\
\text { al., 2015] }\end{array}$ \\
\hline Propionibacterium & $10^{6} \mathrm{CFU} \mathrm{m}^{-1}$ & From birth & Caesarean section & $\begin{array}{l}\text { Pathogenic in } \\
\text { immunocom- } \\
\text { promised } \\
\text { individuals }\end{array}$ & $\begin{array}{l}\text { Coordination of the } \\
\text { immune system } \\
\text { Stimulation of } \\
\text { gastrointestinal motility } \\
\text { Induced expression of } \\
\text { proteins iNOS and COX-2 } \\
\text { by ROS-dependent NF-kB } \\
\text { and AP-1 activation of } \\
\text { macrophages [Jahns et al., } \\
\text { 2015] }\end{array}$ \\
\hline
\end{tabular}

iTreg: regulatory T cells; CFU: colony-forming unit; Th2: lymphocytes; IL: interleukin; TNF- $\alpha$ : tumor necrosis factor-alpha; iNOS: nitric oxide synthase; COX2: induced cyclooxygenase; ROS: reactive oxygen species; NF-kB: transcription factor; AP-1: activator protein 1.

( $\mathrm{T}$ and B cells, macrophages, and dendritic cells) which are located in the intestinal lamina propria, near the epithelium. In the intestinal epithelium, covering Peyer's patches, are specialized cells, known as $\mathrm{M}$ cells, which capture antigens and transmit them to T and B cells. Unlike pathogens, commensal bacteria are unable to penetrate other internal organs or the bloodstream. Weng and Walker reported that antigen stimulation of lymphocytes causes proliferation of naive $\mathrm{T}$ and $\mathrm{B}$ cells, which are activated in the digestive tract, migrate to the lymph vessels and mesenteric lymph nodes, and enter the bloodstream. In the blood, T and B cells are transported back into the lymphatic structures of the digestive tract and the mucous membranes of other systems (respiratory, urogenital, and endocrine glands), where they remain as effector cells. Germ-free animals had only free B cell. Intestinal microflora colonization by commensal bacteria in GF animals stimulates the immune system, resulting in the formation of active Peyer's patches, proliferation of lymphocytes in the lamina propria, and increased production and circulation of secretory antibodies, mainly immunoglobulin A ( $\operatorname{IgA})$ and immunoglobulin $\mathrm{M}$ (IgM). Nonpathogenic intestinal bacteria stimulate the formation of primarily natural antibodies, which are essential components of the nonspecific immune mechanisms and constitute the first line of defense in the immune response [34]. Research in the Institute of Mother and Child in Prague on probiotic strains of E. coli (O86 and Nissle 1917) showed that neonatal E. coli leads to long-term stimulation and production of secretory antibodies. The most commonly used probiotics are strains of E. coli Nissle 1917, Saccharomyces boulardii, and a probiotic mixture containing four strains of Lactobacillus and Bifidobacterium and one of three strains of Streptococcus salivarius [35]. Probiotics may also directly influence the permeability of the intestinal barrier. In the recent studies on epithelial cell lines derived from the colon tissue, it was confirmed that the probiotic Lactobacillus acidophilus restores proinflammatory cytokines such as TNF- $\alpha$ and interferon-gamma (IFN- $\gamma$ ) [36]. Probiotics contribute to the balance of cytokines and can favorably affect the course of those allergic and inflammatory diseases. The clinical effects of probiotics are beneficial and activities of the specific strain cannot be transferred to another strain of the same species. Clinical observations indicate that the probiotic strains may be potentially useful in the treatment of inflammatory diseases [37]. 
2.3. The Impact of Drugs on the Flora. An increased amount of Bifidobacterium was detected in stool samples of people who consume caffeine [38]. The researchers found that smoking and drinking coffee can alter the composition of the intestinal flora. Caffeine in coffee increases the level of granulocyte colony-stimulating (G-CSF) levels, which leads to significant improvement in memory in mice [39].

\subsection{Interaction of Intestinal Flora with Other Systems. Organ-} isms perform a number of metabolic processes, including the synthesis of vitamins B2, B7, and C, which can affect the bioavailability and metabolism of drugs. Some species of bacteria activate the immune system and can cause the development of inflammatory bowel disease (IBD) and other diseases including myasthenia gravis and diabetes [40]. Turnbaugh et al. [41] demonstrated that the intestinal microflora is related to obesity. In the experiment, human intestinal microflora was transferred to GF mouse and was monitored during manipulation of the diet of mice. The introduction of diet resulted in changes after one day [42]. Increasing the energy production by methanogenic bacteria may contribute to the development of obesity. After surgical treatment of obesity, the number of $F$. prausnitzii in patients with type 2 diabetes (T2D) increased but was lower than that in the controls. After surgery, reduced blood glucose, insulin, and glycosylated hemoglobin were noted in patients and there was also decreased resistance to insulin, based on the ELISA results of HOMA-IR (Homeostasis Model Assessment of Insulin Resistance). Some bacteria, such as Firmicutes, contribute to an increase in the absorption of short-chain fatty acids [43]. The effect of lipopolysaccharides and peptidoglycans on the circulatory system by the permeability of the intestinal epithelial barrier stimulates the production of cytokines. These substances have an impact on the synthesis of low-density lipoproteins and can cause damage to the endothelial cells, foam formation, and proliferation of smooth muscle cells [44], the factors that are closely related to the development of atherosclerosis. In patients with heart failure, colorectal microvascular changes may induce the production of cytokines, which contribute to the impaired myocardial function. The bacteria will also be found in the blood circulation, so they may also play a role in the development of heart failure [45]. Sun et al. [46] demonstrated that cathelicidin antimicrobial peptide that is produced in the beta cells of the pancreas in mice with diabetes is also present in normal mice. In another study, intestinal bacteria were transferred from normal mice into the intestine of mice with type 1 diabetes. The bacteria are involved in the initiation of fatty acid production, which leads to the formation of cathelicidin and inhibiting the development of type 1 diabetes [47]. The immune system protects against the invasion of pathogens on the mucosal surface through the production of IgA. [48]. Germ-free animals reduced the number of intestinal intraepithelial $\mathrm{T}$ lymphocytes. $\mathrm{T}$ cells are important for the detection of pathogens and antigen presentation. Intestinal colonization by microorganisms is required for optimal growth, development, and function of the intestinal immune system $[49,50]$. Microbial action on the central nervous system is expressed by modulating cytokine levels. This action also includes changes in the expression of receptors in the brain which affect the interaction of the intestines and the autonomic nervous system, including regulation of the hypothalamicpituitary-adrenal axis [51].

\subsection{The Influence of Gut Flora on the Development and Matu-} ration of the CNS. Changes in the microbiome intestine can lead to abnormal immune responses in both the distal regions of the gut and immune system, that is, the CNS. The microflora modulates the immune system through byproducts (Table 2) [52]. Human intestinal flora can play very important role in the pathogenesis of MS, and recent studies suggest that replacing some of the bacterial population in the gut can lead to a state of the proinflammatory potential mechanism of pathogenesis of MS. Bacteria and their antigenic products may protect against inflammation within the central nervous system of man. Specific bacterial antigens, such as polysaccharides (PSA) from B. fragilis, mediate the migration of microflora, which indicates a significant interaction between the intestinal mucosa and human brain. These observations suggest that populations of effector cells and regulatory $\mathrm{T}$ (Treg) cells are involved in the pathogenesis of MS [53].

Pantazou et al. [54] described the gut-brain axis and demonstrated that intestinal bacteria affect neuroendocrine function and the maturation of the brain by stimulating migration of CD4+ T cells that express CD39 in the brain [55]. Experimental autoimmune encephalomyelitis (EAE) has been used as a model to explore MS and other demyelinating autoimmune diseases of the CNS. Predominantly Th1 and Th17 characterize the immune response to EAE [56]. Lee et al. have shown that oligodendrocyte glycoprotein sensitized mice are susceptible to EAE, but the authors concluded that the segmented bacterial colonization caused her susceptibility [57]. EAE resistant mice were also infected with Lactobacillus casei Shirota [58] and Bifidobacterium animalis, which were found to reduce symptoms [59]. A potential therapeutic strategy for MS is oral administration of probiotic Lactobacillus species, which has been shown to result in IL10-dependent activation of Tregs in the CNS followed by reduction of IFN- $\gamma$, TNF- $\alpha$, and IL-17. Treatment targeting the gut of EAE mice can suppress chronic inflammation. Effect of intestinal microflora may act to both increase and decrease the occurrence of autoimmune diseases by affecting the permeability of the intestinal immune tolerance to the loss of constituents of the microflora and the formation of antibodies to the antigens of intestinal bacteria [60].

2.6. Latitude and Specific Gut Flora. According to Miyake et al. [61], the composition of intestinal microflora in Japanese patients with MS is not significantly different from that of healthy people. However, the analysis of this study by UniFrac showed significant differences $(p<0.05)$ in the overall structure of the intestinal microflora in MS patients and healthy controls. The intestinal microflora in MS patients has greater interindividual variability than that of healthy controls [6264]. This study also showed a decrease in the percentage of several Bacteroides, including B. stercoris, B. coprocola, and 
TABLE 2: Effect of gut microflora on the immune system in MS.

\begin{tabular}{|c|c|c|c|}
\hline Authors & Materials & Models of diseases & Conclusions \\
\hline $\begin{array}{l}\text { Sriram et al. } \\
(1999)\end{array}$ & $\begin{array}{l}17 \text { patients with } \\
\text { relapsing-remitting MS, } \\
20 \text { patients with } \\
\text { progressive MS, and } 27 \\
\text { patients with other } \\
\text { neurological diseases } \\
\text { (OND) }\end{array}$ & MS & $\begin{array}{l}\text { CNS infections; Chlamydia pneumoniae } \\
\text { is a common occurrence in patients with } \\
\text { MS. Although Chlamydia pneumoniae } \\
\text { may be a pathogenic factor of MS, it may } \\
\text { simply be a secondary infection of } \\
\text { damaged tissues of the CNS. }\end{array}$ \\
\hline $\begin{array}{l}\text { Becher et al. } \\
\text { (2001) }\end{array}$ & Mice & EAE & $\begin{array}{l}\text { CD40-CD154 interactions in the CNS are } \\
\text { key determinants for the development } \\
\text { and progression of the disease. } \\
\text { No CD40 expression in cells of the CNS } \\
\text { reduces the intensity and duration of } \\
\text { myelin oligodendrocyte and } \\
\text { glycoprotein-induced EAE and reduces } \\
\text { the degree of infiltration of inflammatory } \\
\text { cells into the CNS. }\end{array}$ \\
\hline $\begin{array}{l}\text { Oksenberg et al. } \\
(2008)\end{array}$ & Mice & EAE & $\begin{array}{l}\text { EAE is considered a model of } \\
\text { autoimmune diseases, including MS. }\end{array}$ \\
\hline $\begin{array}{l}\text { Ezendam and } \\
\text { van Loveren } \\
(2008) ; \\
\text { Ezendam et al. } \\
(2008)\end{array}$ & Mice & EAE & $\begin{array}{c}\text { Reduced symptoms in mice infected with } \\
\text { Lactobacillus casei Shirota and } \\
\text { Bifidobacterium animalis. }\end{array}$ \\
\hline $\begin{array}{l}\text { Yokote et al. } \\
(2008)\end{array}$ & Mice & MS & $\begin{array}{l}\text { Low-calorie diet alleviates the symptoms } \\
\text { of MS. }\end{array}$ \\
\hline $\begin{array}{l}\text { Hawker et al. } \\
(2009)\end{array}$ & $\begin{array}{l}\text { Adults with primary } \\
\text { progressive MS }\end{array}$ & MS & $\begin{array}{l}\text { Rituximab monoclonal antibody, } \\
\text { selective cell killing CD20, proved } \\
\text { effective in reducing disease activity in } \\
\text { relapsing-remitting MS. }\end{array}$ \\
\hline $\begin{array}{l}\text { Lavasani et al. } \\
\text { (2009) }\end{array}$ & $\begin{array}{l}\text { Mice with the strains of } \\
\text { Lactobacillus }\end{array}$ & EAE & $\begin{array}{l}\text { The administration of probiotic lactic } \\
\text { acid has a positive effect on the } \\
\text { autoimmune disease by the production of } \\
\text { IL-10 and stimulation of Treg cells. }\end{array}$ \\
\hline $\begin{array}{l}\text { Barnett et al. } \\
(2009)\end{array}$ & $\begin{array}{c}\text { Patients with MS and } \\
\text { other neurological } \\
\text { diseases }\end{array}$ & MS & IgG disrupted myelin in MS. \\
\hline $\begin{array}{l}\text { Ochoa et al. } \\
(2010)\end{array}$ & $\begin{array}{c}\text { Mice after treatment } \\
\text { with antibiotics and } \\
\text { infected with } B \text {. fragilis }\end{array}$ & EAE & $\begin{array}{l}\text { Antibiotic therapy can protect against } \\
\text { EAE; a similar effect is observed for } B \text {. } \\
\text { fragilis (commensal bacteria). }\end{array}$ \\
\hline $\begin{array}{l}\text { Farooqi et al. } \\
(2010)\end{array}$ & Mice & EAE & $\begin{array}{l}\text { EAE has similar features to inflammation, } \\
\text { demyelination, axonal loss, and gliosis. }\end{array}$ \\
\hline Lee et al. (2011) & Mice & EAE & SFB induce Th17 immune response. \\
\hline $\begin{array}{l}\text { Farrokhi et al. } \\
\text { (2013) }\end{array}$ & $\begin{array}{l}\text { Patients with and } \\
\text { without MS } \\
\text { concentration of lipid } \\
624 \\
\end{array}$ & MS & $\begin{array}{l}\text { Lipid } 624 \text { (TLR2 ligand) occurs in lower } \\
\text { concentrations in patients with MS [12]. }\end{array}$ \\
\hline $\begin{array}{l}\text { Rumah et al. } \\
\text { (2013) }\end{array}$ & $\begin{array}{l}\text { Patients with MS and } \\
\text { healthy individuals }\end{array}$ & MS & $\begin{array}{l}\text { CSF obtained from two tissues; immunity } \\
\text { to ETX is } 10 \text { times more frequent in } \\
\text { individuals with MS compared to healthy } \\
\text { subjects, indicating prior exposure to } \\
\text { ETX in MS population. }\end{array}$ \\
\hline $\begin{array}{l}\text { Chiurchiù et al. } \\
\text { (2013) }\end{array}$ & $\begin{array}{l}\text { Healthy people and MS } \\
\text { patients }\end{array}$ & MS & $\begin{array}{l}\text { pDC from patients with MS and } \\
\text { production of higher levels of } \\
\text { interleukin- } 12 \text { and interleukin- } 6 \text {, whereas } \\
\text { pDC had lower levels of interferon- } \alpha \\
\text { compared to healthy subjects. }\end{array}$ \\
\hline
\end{tabular}


TABLE 2: Continued.

\begin{tabular}{|c|c|c|c|}
\hline Authors & Materials & Models of diseases & Conclusions \\
\hline $\begin{array}{l}\text { Tauschmann et } \\
\text { al. }(2013)\end{array}$ & Healthy young people & $\begin{array}{l}\text { Autoimmune } \\
\text { disease }\end{array}$ & $\begin{array}{l}\text { The imbalance between the bacteria and } \\
\text { the intestinal immune system leading to } \\
\text { overstimulation of the immune } \\
\text { system.Treg cells have inhibitory effects } \\
\text { on the cells in autoimmune diseases. }\end{array}$ \\
\hline $\begin{array}{l}\text { Reichelt et al. } \\
(2014)\end{array}$ & Patients with MS & MS & $\begin{array}{l}\text { The increase of IgA may be secondary to } \\
\text { an increase in the intestinal absorption. }\end{array}$ \\
\hline $\begin{array}{l}\text { Miyake et al. } \\
(2015)\end{array}$ & Patients with MS & MS & $\begin{array}{l}\text { Patients with MS are characterized by } \\
\text { moderate dysbiosis. The decrease in the } \\
\text { percentage of several Bacteroides, } \\
\text { including B. stercoris, B. coprophilus, and } \\
\text { B. coprocola. }\end{array}$ \\
\hline $\begin{array}{l}\text { Nicol et al. } \\
(2015)\end{array}$ & Mice & EAE & $\begin{array}{l}\text { Reduction of the severity of symptoms } \\
\text { after antibiotic treatment. } \\
\text { Decrease in the amount of IFN- } \gamma \text {, MIP-1a, } \\
\text { MIP-1 p, MCP-1, IL-17, and IL- } 6 \text { and } \\
\text { increase in the amount of IL-10 and IL } 13 \text {. }\end{array}$ \\
\hline
\end{tabular}

EAE: experimental autoimmune encephalomyelitis; B. fragilis: Bacteroides fragilis; IL: interleukin; Treg: regulatory T cells; MS: multiple sclerosis; SFB: segmented filamentous bacteria; TLR2: Toll-like receptor 2; IgG: immunoglobulin G; Th17: T helper 17 cell; IFN- $\gamma$ : interferon-gamma; MIP: macrophage inflammatory proteins; MCP-1: monocyte chemoattractant protein-1; IgA: immunoglobulin A; CSF: cerebrospinal fluid; C. perfringens: Clostridium perfringens; CD 40: cluster of differentiation 40; CD 154: cluster of differentiation 154; CNS: central nervous system; ETX: epsilon-toxin; pDC: proportion of days covered.

B. coprophilus in the intestinal microflora in patients with MS [61].

2.7. Effect of Flora on Cytokines in MS. An imbalance of intestinal bacteria, intestinal epithelial cells, and cells of the immune system in the intestinal mucosa can lead to overstimulation of the immune system. Suppression of excessive immune stimulation is controlled by Treg cells, a distinct population of $\mathrm{CD} 4+\mathrm{T}$ cells produced in the thymus and peripheral organs of the immune system (e.g., GALT). Tregs have inhibitory effects on inflammatory cell populations and autoreactive effector cells. Treg function defects occur frequently in autoimmune diseases such as rheumatoid arthritis, systemic lupus erythematosus (SLE), and MS [65].

According to Berer and Krishnamoorthy [66], there is increasing evidence from animal studies of a relationship between the type of gut microflora and the progression of MS. Autoimmune reactions can be produced by molecular mimicry or by stimulating the production of lymphocytes. Metabolites produced by these bacteria can also affect the autoimmune system. Multiple sclerosis is a demyelinating disease, which coincides with inflammatory processes [67]. Whether bacterial pathogens act as initiators of MS is not entirely clear. The intestinal microflora can produce various metabolic by-products that affect the CNS, causing reduced autoimmunity. These by-products include short-chain fatty acids (acetic acid, butyric acid, and propionic acid) which bind to the anti-binding $G$ protein coupled receptor (GPCR) and produce Treg, which suppresses proinflammatory cytokines and antigen presenting cells. Adenosine triphosphate stimulates the production of Th17 inflammatory cells, which can cause autoimmune reactions in the CNS [68]. This can adversely affect the commensal bacteria Bacteroides fragilis and cause T cell differentiation to Th1, IL-10, and Treg [6971].

Farrokhi et al. [72] demonstrated unique lipodipeptide bacteria which originate from serine lipodipeptide, lipid 654, which is produced by some Bacteroidetes commensal species, and act as ligand-receptor, providing further evidence for an association between the bacteria and the MS. Kleinewietfeld et al. [73] demonstrated that lipid 654 is expressed at much lower levels in the serum of MS patients than in healthy controls. Lipid 654 may be biomarker of MS [72]. Furthermore, these bacteria produce a number of metabolic products known as the metabolome of by-products which could cause activation of the immune system.

2.8. Effect of the Flora on MS Symptoms. The earliest noticeable changes in the permeability of the blood-brain barrier are oligodendrocyte apoptosis and microglial activation [74]. At that time, demyelination is still visible [75-77]. Soluble toxins may be initiating factors in MS. Natural toxin of Clostridium perfringens or toxins $\mathrm{B}$ and $\mathrm{D}$ influence neurological symptoms [78-82]. The toxins are absorbed by the intestine, enter the bloodstream, and cause MS-like symptoms (e.g., blurred vision, lack of coordination, or spastic paralysis). Murrell et al. [83] first suggested that exotoxins could be a potential cause of MS, as humans are not natural hosts of $C$. perfringens types B or D [84-87]. Exotoxins bind to receptors present in the vascular system of the brain and in both myelinated and unmyelinated brain regions, such as the corpus callosum [88-91]. Osmolysis occurs upon binding to the receptor [92-96]. Dawson [97] first described the morphology of relapsing multiple sclerosis. Binding of retinal vein which forms a barrier to the CNS may explain the occurrence of periphlebitis retinae in MS patients $[98,99]$. Toxins affect 
the barrier veins, which may cause inflammation of the retina. Periventricular accumulation of monocytes is often observed [77]. During the test, the effect of intestinal microflora has been shown that the colonized mice had more symptoms become severe and inflammation [100]. This was demonstrated in another animal model of MS [101]. Dendritic cells (DCs) may not activate T cells to an autoantigen as effectively as DCs in colonized animals. Commensal bacteria can act as either the preferred symbiont or a disease-promoting pathobiont, depending on the target of the autoimmune disease, different effector mechanisms, and the composition of the intestinal flora [102].

2.9. Effect of Immunomodulatory Agents in MS on the Gut Flora. Further evidence of a link between bacteria in the gut and MS is the decreased concentration of Faecalibacterium in patients with MS compared with healthy subjects [103]. Butyrate production is associated with increased numbers of Treg cells, which suggests a potential mechanism through which changes in the intestinal microbiome may lead to predisposition for developing MS. Patients with MS treated with glatiramer acetate have less Bacteroidaceae, Faecalibacterium, Ruminococcus, Lactobacillaceae, Clostridium, and other members of the Clostridiales class compared with untreated MS patients. The study compared 3 groups: healthy subjects, patients with MS who are treated, and patients who are not treated. In response to vitamin D supplementation, only MS patients who did not undergo glatiramer acetate treatment showed an increase in the number of Akkermansia, Faecalibacterium, and Coprococcus. It was recently discovered that intestinal colonization by the Clostridium perfringens type B is associated with relapse in MS. Toxins produced by $C$. perfringens can lead to microvascular complications leading to neuronal and oligodendrocyte damage [104-107], which may serve as a trigger for future demyelinating events in susceptible individuals. Jhangi et al. [108] compared MS patients with healthy subjects and observed increased concentrations of Archaea (Methanobrevibacter) and decreased concentrations of Butyricimonas and Lachnospiraceae in MS patients.

According to Wekerle [8], MS also arises from a negative interaction between genetics and environmental factors. A large number of genes promote an autoimmune response against brain cells. New experimental and clinical studies indicate that autoimmune attacks are triggered by an interaction between immune cells of the brain and the gut microbiota. These findings may contribute to the development of new therapeutics that modulate gut microbiota.

Cannabinoid receptors in the intestinal tissue are activated by ligands of cannabinoids that may activate cannabinoid receptors in other local systems. Chiurchiù et al. [109] discovered that treatment of MS patients with anandamide affects the cannabinoid receptors and leads to a decrease in TNF- $\alpha$ and IL- 6 production. Recent discoveries have shown that specific microorganisms of the intestinal microflora can improve the clinical symptoms of EAE; that is, strains of lactic acid bacteria can enhance the immunological activity of $B$ cells and Treg by increased production of IL-10.

According to Miller et al. [110], MS is an autoimmune disease of the brain, because antagonists of TNF-1 improve the condition of many patients with autoimmune disease (e.g., Crohn's disease, ankylosing spondylitis, and rheumatoid arthritis). TNFR2 deficiency causes spontaneous autoimmune-driven demyelination in the brains of transgenic female mice and increases the levels of IL-17, IFN- $\gamma$, and IgG2b. This is due to the composition of intestinal microflora, as autoimmunity persists after oral antibiotics. Another result of this study is the impact of the type of intestinal microflora (Akkermansia muciniphila, Sutterella stercoricanis, Oscillospira, Bacteroides acidifaciens, and Anaeroplasma) in male mice in the Alpine resort, where the microflora resulted in a protective effect.

However, the microflora of female mice mainly consisted of Bacteroides sp., Bacteroides uniformis, and Parabacteroides, which influenced the brain's autoimmune system. Commensal gut bacteria affect TNFR2 levels, which can cause autoimmune-driven demyelination in mice. Therefore, microflora can contribute to the autoimmune response of TNF in autoimmune diseases of the brain.

Messaoudi et al.[111] reported that EAE CD4+ cells directed against self-antigens pass into the CNS and cause demyelination. Many animals were treated with antibiotic therapy in order to reduce the intestinal microbiota. Antibiotics change the amount and composition of the intestinal flora and can reduce the clinical symptoms of autoimmune diseases of the brain. In the EAE model, broad-spectrum antibiotics reduced the susceptibility to EAE by altering the population of T cells in the GALT and peripheral lymphoid tissues. The growth of lymphocytes provided a protective role against EAE. CD5+ and CD19+ in the distant lymphoid organs decrease the levels of IFN- $\gamma$, MIP-1a, MIP-1b, MCP-1, IL-17, and IL- 6 and increase IL-10 and IL-13 [112]. Small changes in Th1 and Th17 lead to an anti-inflammatory Th2 response. Th1 and Th17 contribute to MS progression, while FOXP3+ Treg cells play a protective role. These results indicate that the change in the composition of the intestinal flora due to antibiotic therapy may be beneficial in the treatment of MS [113]. Segmented filamentous bacteria are related to the introduction of Th17 and have been shown to influence autoimmune diseases [114].

2.10. The Effect of Diet on Gut Flora. Diet plays an important role in shaping the gut microbiome. In adults, a change in diet can produce a change in the intestinal microflora. One study found a plant-based diet, which leads to an increase in the population of Firmicutes (Roseburia, Ruminococcus bromii, and Eubacterium rectale) and the transition to a meat-based diet leads to an increase in the number of Alistipes, Bilophila, and Bacteroides [115]. Diet may influence the course of MS. Intestinal microbiota can modulate the effects of autoimmune diseases in humans $[57,116]$. Th17 cells were shown to induce divided filamentous bacteria, which play an important role in the pathogenesis of autoimmune disease [117-119]. Some metabolites of commensal bacteria introduce FOXP3 positive Treg cells into the colon [120]. The gut has its own mechanism for the elimination of proinflammatory Th17 cells [12]. Studies have shown that consumption of Candida could be a new therapeutic strategy for the autoimmune system. This study 
suggested that dietary yeast might be an important treatment for autoimmune diseases. Pathological examination showed that the amount of MNC (mononuclear cells) in the spinal cord of mice was lower than those in the control group, which was not treated.

Riccio and Rossano [121] reported that diet can influence the severity of MS in both relapsing-remitting MS and primary progressive MS. Diet can have an impact on symptoms of MS by controlling metabolic processes, inflammatory cells, and the composition of commensal intestinal microflora. Increased permeability of the intestinal barrier can lead to cross-reactivity between proteins, leading to the production of IgG and IgA. A diet high in salt, animal fat, red meat, sugarsweetened beverages, carbohydrates, and fiber, in addition to a lack of physical activity, may increase symptoms, as these all influence metabolism and can lead to dysbiotic intestinal microflora, low-grade systemic inflammation, and increased permeability of the intestinal barrier. A low calorie diet of vegetables, fruits, legumes, fish, prebiotics, and probiotics can reduce symptoms by maintaining a healthy intestinal microflora symbiosis. These results indicate that microflora changes may cause activation of proinflammatory agents and may contribute to relapse in MS [122].

Burkitt [123] first described the potential protective effect of diet on bowel disease.

While working in Africa in 1960, he noticed a remarkable lack of noncommunicable diseases in the native Africans who consumed the traditional diet, which was rich in fiber. Antimicrobial peptides such as alpha-defensins, which are released by Paneth cells, may also have a significant effect on endogenous bacterial flora.

The reduction in the amount of microorganisms in the intestine is most likely to be an adverse effect of globalization, which leads to the consumption of generic, nutrient-rich, uncontaminated food. Both in the Western world and in developing countries, a diet high in fat, protein, and sugar and low in absorbable fibers is associated with a rapid increase in the incidence of noninfectious intestinal diseases [124].

The transition from a diet rich in fiber and low in fat to a high-fat diet alters the composition of the bacterial flora as early as after day 1 [41]. The intestinal flora of children from nonurban areas of Africa is rich in species, including Prevotella and Xylanibacter, which break abundant fiber. The resulting distribution of short-chain fatty acids in the flora has immunomodulating properties, which may explain the lower incidence of autoimmune diseases and asthma in these environments [125]. In contrast, animals given "Western" diets have high energy, due to the high sugar and fat content, lower levels of Bacteroidetes, and increased levels of Actinobacteria [41].

The relationship between the CNS, immune system, and gut microflora is associated with the development of MS. Possible interactions between the intestinal microflora and immune system can be examined by altering the endocannabinoid system to understand the interactions in the braingut axis [126].

\section{Summary}

The etiopathogenesis of MS is not fully known. Studies suggest that risk factors include viral infections, vitamin $\mathrm{D}$ deficiency, and smoking. There is also evidence to suggest that gut microflora could be important in the pathogenesis of MS. Recent studies have shown that replacing some of the bacterial population in the gut can lead to a proinflammatory state, indicating a potential mechanism causing MS in humans [53]. Furthermore, the intestinal microflora in MS patients has greater interindividual variability than that of healthy controls [62-64]. In contrast to other commensal bacteria, their antigenic products may protect against inflammation within the CNS. These results indicate that the intestinal microflora in patients with MS is characterized by moderate dysbiosis. Miyake et al. in their study also showed a decrease in the percentage of several Bacteroides, including Bacteroides stercoris, Bacteroides coprocola, and Bacteroides coprophilus in the intestinal microflora in patients with MS [61]. The results suggest a negative correlation between Prevotella copri and the pathogenesis of MS [61]. According to Ochoa-Repáraz et al., intestinal flora may affect the pathogenesis of MS, as changes in the gut microbiome lead to an irregular immune response, in both the colon and distal regions of the immune system, that is, the CNS. Specific bacterial antigens, such as PSA from Bacteroides fragilis, mediate the migration of the CNS, indicating a substantial interaction between the intestinal mucosa and the brain [69]. These observations suggest that the population of effector cells and regulatory cells involved in the pathogenesis of MS in humans may be associated with the lymphoid tissue of the gut [53]. Patients with MS had reduced concentrations of Faecalibacterium [103]. Furthermore, MS patients treated with glatiramer acetate showed an increase in Bacteroidaceae, Faecalibacterium, Ruminococcus, Lactobacillaceae, Clostridium, and other members of the class Clostridiales when compared with untreated MS patients.

\section{Abbreviations}

$\begin{array}{ll}\text { ATP: } & \text { Adenosine triphosphate } \\ \text { CCL4: } & \text { Chemokine ligand } 4 \\ \text { CCL5: } & \text { Chemokine ligand } 5 \\ \text { CD4: } & \text { Cluster of differentiation } 4 \\ \text { CD8: } & \text { Cluster of differentiation } 8 \\ \text { CD39: } & \text { Cluster of differentiation 39 } \\ \text { CNS: } & \text { Central nervous system } \\ \text { CRP: } & \text { C-Reactive protein } \\ \text { DNA: } & \text { Deoxyribonucleic acid } \\ \text { EAE: } & \text { Experimental autoimmune encephalomyelitis } \\ \text { EBV: } & \text { Epstein-Barr virus } \\ \text { ELISA: } & \text { Enzyme-linked immunosorbent assay } \\ \text { FOXP3: } & \text { Forkhead box P3 } \\ \text { GALT: } & \text { Gut-associated lymphoid tissue } \\ \text { G-CSF: } & \text { Granulocyte colony-stimulating factor } \\ \text { GF: } & \text { Germ-free } \\ \text { GPRS: } & \text { Binding G protein coupled receptor } \\ \text { GWAS: } & \text { Genome-wide association studies } \\ \text { HOMA-IR: } & \text { Homeostasis Model Assessment of Insulin } \\ & \text { Resistance }\end{array}$


HPA: Hypothalamic-pituitary-adrenal

IFN: Interferon

Ig: Immunoglobulin

IL: Interleukin

IgG2b: PE anti-mouse antibody

IP-10: Interferon-gamma-induced protein 10

LPS: Lipopolysaccharide

MCP-1: Monocyte chemoattractant protein-1

MHC: Major histocompatibility complex

MIP-1: Macrophage inflammatory protein 1

MS: $\quad$ Multiple sclerosis

p: $\quad$ Probability value

PSA: Polysaccharide A

ROS: Reactive oxygen species

RNS: Reactive nitrogen species

SCFA: Short-chain fatty acid

SLE: Systemic lupus erythematosus

SNP: Single-nucleotide polymorphism

Th1: Th cells

TLR: Toll-like receptors

TNF: Tumor necrosis factor

TNFR2: Tumor necrosis factor receptor 2

Treg: $\quad$ Regulatory T lymphocytes

UVR: Ultraviolet radiation.

\section{Competing Interests}

The authors declare that they have no competing interests.

\section{References}

[1] T. Kalincik, "Multiple sclerosis relapses: epidemiology, outcomes and management. A systematic review," Neuroepidemiology, vol. 44, no. 4, pp. 199-214, 2015.

[2] A. Nylander and D. A. Hafler, "Multiple sclerosis," The Journal of Clinical Investigation, vol. 122, no. 4, pp. 1180-1188, 2012.

[3] M. Sospedra and R. Martin, "Immunology of multiple sclerosis," Annual Review of Immunology, vol. 23, pp. 683-747, 2005.

[4] D. M. Williamson, J. P. Henry, R. Schiffer, and L. Wagner, "Prevalence of multiple sclerosis in 19 texas counties, 1998-2000," Journal of Environmental Health, vol. 69, no. 10, pp. 41-45, 2007.

[5] J. Correale and M. F. Farez, "The role of astrocytes in multiple sclerosis progression," Frontiers in Neurology, vol. 6, article 180, 2015.

[6] E. Miller, B. Wachowicz, and I. Majsterek, "Advances in antioxidative therapy of multiple sclerosis," Current Medicinal Chemistry, vol. 20, no. 37, pp. 4720-4730, 2013.

[7] M. Weng and W. A. Walker, "The role of gut microbiota in programming the immune phenotype," Journal of Developmental Origins of Health and Disease, vol. 4, no. 3, pp. 203-214, 2013.

[8] H. Wekerle, "Nature plus Nurture* : the triggering of multiple sclerosis," Swiss Medical Weekly, vol. 145, 2015.

[9] A. K. Hedström, L. Alfredsson, and T. Olsson, "Environmental factors and their interactions with risk genotypes in MS susceptibility," Current Opinion in Neurology, vol. 29, no. 3, pp. 293298, 2016.

[10] L. Handunnetthi, S. V. Ramagopalan, and G. C. Ebers, "Multiple sclerosis, vitamin D, and HLA-DRB1*15," Neurology, vol. 74, no. 23, pp. 1905-1910, 2010.
[11] S. Alotaibi, J. Kennedy, R. Tellier, D. Stephens, and B. Banwell, "Epstein-barr virus in pediatric multiple sclerosis," JAMA, vol. 291, no. 15, pp. 1875-1879, 2004.

[12] E. Esplugues, S. Huber, N. Gagliani et al., "Control of TH17 cells occurs in the small intestine," Nature, vol. 475, no. 7357, pp. 514518, 2011.

[13] K. L. Munger, K. C. Fitzgerald, M. S. Freedman et al., "No association of multiple sclerosis activity and progression with EBV or tobacco use in BENEFIT,' Neurology, vol. 85, no. 19, pp. 16941701, 2015.

[14] S. Jilek, M. Schluep, P. Meylan et al., "Strong EBV-specific CD8+ T-cell response in patients with early multiple sclerosis," Brain, vol. 131, no. 7, pp. 1712-1721, 2008.

[15] E. Jaquiéry, S. Jilek, M. Schluep et al., "Intrathecal immune responses to EBV in early MS," European Journal of Immunology, vol. 40, no. 3, pp. 878-887, 2010.

[16] R. T. Ross, L. E. Nicolle, M. R. Dawood, M. Cheang, and C. Feschuk, "Varicella zoster antibodies after herpes zoster, varicella and multiple sclerosis," Canadian Journal of Neurological Sciences, vol. 24, no. 2, pp. 137-139, 1997.

[17] S.-M. Orton, L. Wald, C. Confavreux et al., "Association of UV radiation with multiple sclerosis prevalence and sex ratio in France," Neurology, vol. 76, no. 5, pp. 425-431, 2011.

[18] T. Spelman, O. Gray, M. Trojano et al., "Seasonal variation of relapse rate in multiple sclerosis is latitude dependent," Annals of Neurology, vol. 76, no. 6, pp. 880-890, 2014.

[19] A. Ascherio, K. L. Munger, R. White et al., "Vitamin D as an early predictor of multiple sclerosis activity and progression," JAMA Neurology, vol. 71, no. 3, pp. 306-314, 2014.

[20] R. Dobson, G. Giovannoni, and S. Ramagopalan, "The month of birth effect in multiple sclerosis: systematic review, meta-analysis and effect of latitude," Journal of Neurology, Neurosurgery and Psychiatry, vol. 84, no. 4, pp. 427-432, 2013.

[21] T. B. Alberti, R. Marcon, M. A. Bicca, N. R. B. Raposo, J. B. Calixto, and R. C. Dutra, "Essential oil from Pterodon emarginatus seeds ameliorates experimental autoimmune encephalomyelitis by modulating Th1/Treg cell balance," Journal of Ethnopharmacology, vol. 155, no. 1, pp. 485-494, 2014.

[22] B. D. Trapp, R. M. Ransohoff, E. Fisher, and R. A. Rudick, "Neurodegeneration in multiple sclerosis: relationship to neurological disability," Neuroscientist, vol. 5, no. 1, pp. 48-57, 1999.

[23] G. S. H. Chelune and J. Pinkston, "Multiple sclerosis," in Textbook of Clinical Neuropsychology, pp. 599-615, 2008.

[24] D. B. DiGiulio, R. Romero, H. P. Amogan et al., "Microbial prevalence, diversity and abundance in amniotic fluid during preterm labor: a molecular and culture-based investigation," PLoS ONE, vol. 3, no. 8, Article ID e3056, 2008.

[25] M. G. Dominguez-Bello, E. K. Costello, M. Contreras et al., "Delivery mode shapes the acquisition and structure of the initial microbiota across multiple body habitats in newborns," Proceedings of the National Academy of Sciences of the United States of America, vol. 107, no. 26, pp. 11971-11975, 2010.

[26] I. Mukhopadhya, R. Hansen, C. Meharg et al., "The fungal microbiota of de-novo paediatric inflammatory bowel disease," Microbes and Infection, vol. 17, no. 4, pp. 304-310, 2015.

[27] J. E. Koenig, A. Spor, N. Scalfone et al., "Succession of microbial consortia in the developing infant gut microbiome," Proceedings of the National Academy of Sciences of the United States of America, vol. 108, no. 1, pp. 4578-4585, 2011.

[28] C. Palmer, E. M. Bik, D. B. DiGiulio, D. A. Relman, and P. O. Brown, "Development of the human infant intestinal microbiota," PLOS biology, vol. 5, no. 7, 2007. 
[29] D. Mariat, O. Firmesse, F. Levenez et al., "The firmicutes/bacteroidetes ratio of the human microbiota changes with age," BMC Microbiology, vol. 9, article no. 123, 2009.

[30] J. Collins, R. Borojevic, E. F. Verdu, J. D. Huizinga, and E. M. Ratcliffe, "Intestinal microbiota influence the early postnatal development of the enteric nervous system," Neurogastroenterology and Motility, vol. 26, no. 1, pp. 98-107, 2014.

[31] K. M. Tuohy, S. Kolida, A. M. Lustenberger, and G. R. Gibson, "The prebiotic effects of biscuits containing partially hydrolysed guar gum and fructo-oligosaccharides-a human volunteer study," British Journal of Nutrition, vol. 86, no. 3, pp. 341-348, 2001.

[32] K. M. Tuohy, C. J. Ziemer, A. Klinder, Y. Knöbel, B. L. PoolZobel, and G. R. Gibson, "A human volunteer study to determine the prebiotic effects of lactulose powder on human colonic microbiota," Microbial Ecology in Health and Disease, vol. 14, no. 3, pp. 165-173, 2002.

[33] W. Strober, "Inside the microbial and immune labyrinth: gut microbes: friends or fiends?" Nature Medicine, vol. 16, no. 11, pp. 1195-1197, 2010.

[34] B. Cukrowska, H. Kozáková, Z. Řeháková, J. Šinkora, and H. Tlaskalová-Hogenová, "Specific antibody and immunoglobulin responses after intestinal colonization of germ-free piglets with non-pathogenic Escherichia coli O86," Immunobiology, vol. 204, no. 4, pp. 425-433, 2001.

[35] B. Cukrowska, R. Lodínová-Žádníková, C. Enders, U. Sonnenborn, J. Schulze, and H. Tlaskalová-Hogenová, "Specific proliferative and antibody responses of premature infants to intestinal colonization with nonpathogenic probiotic E. coli strain Nissle 1917," Scandinavian Journal of Immunology, vol. 55, no. 2, pp. 204-209, 2002.

[36] S. Resta-Lenert and K. E. Barrett, "Probiotics and commensals reverse TNF- $\alpha$ - and IFN- $\gamma$-induced dysfunction in human intestinal epithelial cells," Gastroenterology, vol. 130, no. 3, pp. 731-746, 2006.

[37] S. Travis, "Advances in therapeutic approaches to ulcerative colitis and crohn's disease," Current Gastroenterology Reports, vol. 7, no. 6, pp. 475-484, 2005.

[38] M. Jaquet, I. Rochat, J. Moulin, C. Cavin, and R. Bibiloni, "Impact of coffee consumption on the gut microbiota: A Human Volunteer Study," International Journal of Food Microbiology, vol. 130, no. 2, pp. 117-121, 2009.

[39] P. Derkinderen, K. M. Shannon, and P. Brundin, "Gut feelings about smoking and coffee in Parkinson's disease," Movement Disorders, vol. 29, no. 8, pp. 976-979, 2014.

[40] Y. Belkaid and T. W. Hand, "Role of the microbiota in immunity and inflammation," Cell, vol. 157, no. 1, pp. 121-141, 2014.

[41] P. J. Turnbaugh, V. K. Ridaura, J. J. Faith, F. E. Rey, R. Knight, and J. I. Gordon, "The effect of diet on the human gut microbiome: a metagenomic analysis in humanized gnotobiotic mice," Science Translational Medicine, vol. 1, no. 6, Article ID 6ra14, 2009.

[42] B. S. Samuel, E. E. Hansen, J. K. Manchester et al., "Genomic and metabolic adaptations of Methanobrevibacter smithii to the human gut," Proceedings of the National Academy of Sciences of the United States of America, vol. 104, no. 25, pp. 10643-10648, 2007.

[43] Z. Wang, E. Klipfell, B. J. Bennett et al., "Gut flora metabolism of phosphatidylcholine promotes cardiovascular disease," Nature, vol. 472, no. 7341, pp. 57-63, 2011.

[44] P. Robinet, Z. Wang, S. L. Hazen, and J. D. Smith, "A simple and sensitive enzymatic method for cholesterol quantification in macrophages and foam cells," Journal of Lipid Research, vol. 51, no. 11, pp. 3364-3369, 2010.

[45] Y. Nagatomo and W. H. W. Tang, "Intersections between microbiome and heart failure: revisiting the gut hypothesis," Journal of Cardiac Failure, vol. 21, no. 12, pp. 973-980, 2015.

[46] J. Sun, L. Furio, R. Mecheri et al., "Pancreatic $\beta$-cells limit autoimmune diabetes via an immunoregulatory antimicrobial peptide expressed under the influence of the gut microbiota," Immunity, vol. 43, no. 2, pp. 304-317, 2015.

[47] M. Kasubuchi, S. Hasegawa, T. Hiramatsu, A. Ichimura, and I. Kimura, "Dietary gut microbial metabolites, short-chain fatty acids, and host metabolic regulation," Nutrients, vol. 7, no. 4, pp. 2839-2849, 2015.

[48] H. L. Cash, C. V. Whitham, C. L. Behrendt, and L. V. Hooper, "Symbiotic bacteria direct expression of an intestinal bactericidal lectin," Science, vol. 313, no. 5790, pp. 1126-1130, 2006.

[49] The International Multiple Sclerosis Genetics Consortium (IMSGC), "Evidence for polygenic susceptibility to multiple sclerosis-the shape of things to come," American Journal of Human Genetics, vol. 86, no. 4, pp. 621-625, 2010.

[50] S. Sawcer, G. Hellenthal, and M. Pirinen, "Genetic risk and a primary role for cellmediated immune mechanisms in multiple sclerosis," Nature, vol. 476, pp. 214-219, 2011.

[51] K. H. Collins, H. A. Paul, R. A. Reimer, R. A. Seerattan, D. A. Hart, and W. Herzog, "Relationship between inflammation, the gut microbiota, and metabolic osteoarthritis development: studies in a rat model," Osteoarthritis and Cartilage, vol. 23, no. 11, pp. 1989-1998, 2015.

[52] I. I. Ivanov, R. D. L. Frutos, N. Manel et al., "Specific microbiota direct the differentiation of IL-17-producing T-helper cells in the mucosa of the small intestine," Cell Host and Microbe, vol. 4, no. 4, pp. 337-349, 2008.

[53] S. Lavasani, B. Dzhambazov, M. Nouri et al., "A novel probiotic mixture exerts a therapeutic effect on experimental autoimmune encephalomyelitis mediated by IL-10 producing regulatory T cells," PLOS ONE, vol. 5, 2010.

[54] V. Pantazou, M. Schluep, and R. Du Pasquier, "Environmental factors in multiple sclerosis," Presse médicale, vol. 44, no. 4, pp. e113-e120, 2015.

[55] Z. M. Earley, S. Akhtar, S. J. Green et al., "Burn injury alters the intestinal microbiome and increases gut permeability and bacterial translocation," PLOS ONE, vol. 10, no. 7, Article ID e0129996, 2015.

[56] J. R. Oksenberg, S. E. Baranzini, S. Sawcer, and S. L. Hauser, "The genetics of multiple sclerosis: SNPs to pathways to pathogenesis," Nature Reviews Genetics, vol. 9, no. 7, pp. 516-526, 2008.

[57] Y. K. Lee, J. S. Menezes, Y. Umesaki, and S. K. Mazmanian, “Proinflammatory T-cell responses to gut microbiota promote experimental autoimmune encephalomyelitis," Proceedings of the National Academy of Sciences of the United States of America, vol. 108, no. 1, pp. 4615-4622, 2011.

[58] J. Ezendam and H. van Loveren, "Lactobacillus casei Shirota administered during lactation increases the duration of autoimmunity in rats and enhances lung inflammation in mice," British Journal of Nutrition, vol. 99, no. 1, pp. 83-90, 2008.

[59] J. Ezendam, A. De Klerk, E. R. Gremmer, and H. Van Loveren, "Effects of Bifidobacterium animalis administered during lactation on allergic and autoimmune responses in rodents," Clinical and Experimental Immunology, vol. 154, no. 3, pp. 424-431, 2008. 
[60] M. Banati, P. Csecsei, E. Koszegi et al., "Antibody response against gastrointestinal antigens in demyelinating diseases of the central nervous system," European Journal of Neurology, vol. 20, no. 11, pp. 1492-1495, 2013.

[61] S. Miyake, S. Kim, W. Suda et al., "Dysbiosis in the gut microbiota of patients with multiple sclerosis, with a striking depletion of species belonging to clostridia XIVa and IV clusters," PLOS ONE, vol. 10, no. 9, Article ID e0137429, 2015.

[62] D. N. Frank, A. L. St Amand, R. A. Feldman, E. C. Boedeker, N. Harpaz, and N. R. Pace, "Molecular-phylogenetic characterization of microbial community imbalances in human inflammatory bowel diseases," Proceedings of the National Academy of Sciences of the United States of America, vol. 104, no. 34, pp. 13780-13785, 2007.

[63] D. A. Peterson, D. N. Frank, N. R. Pace, and J. I. Gordon, "Metagenomic approaches for defining the pathogenesis of inflammatory bowel diseases," Cell Host and Microbe, vol. 3, no. 6, pp. 417-427, 2008.

[64] J. Qin, R. Li, J. Raes et al., "A human gut microbial gene catalogue established by metagenomic sequencing," Nature, vol. 464, no. 7285, pp. 59-65, 2010.

[65] M. Tauschmann, B. Prietl, G. Treiber et al., "Distribution of CD4(pos)-, CD8(pos)- and regulatory T cells in the upper and lower gastrointestinal tract in healthy young subjects," PLoS ONE, vol. 8, Article ID e80362, 2013.

[66] K. Berer and G. Krishnamoorthy, "Microbial view of central nervous system autoimmunity," FEBS Letters, vol. 588, no. 22, pp. 4207-4213, 2014.

[67] B. Becher, B. G. Durell, A. V. Miga, W. F. Hickey, and R. J. Noelle, "The clinical course of experimental autoimmune encephalomyelitis and inflammation is controlled by the expression of CD40 within the central nervous system," Journal of Experimental Medicine, vol. 193, no. 8, pp. 967-974, 2001.

[68] E. W. Pomare, W. J. Branch, and J. H. Cummings, "Carbohydrate fermentation in the human-colon and its relation to acetate concentrations in venous-blood," The Journal of Clinical Investigation, vol. 75, no. 5, pp. 1448-1454, 1985.

[69] J. Ochoa-Repáraz, D. W. Mielcarz, S. Haque-Begum, and L. H. Kasper, "Induction of a regulatory B cell population in experimental allergic encephalomyelitis by alteration of the gut commensal microflora," Gut Microbes, vol. 1, no. 2, pp. 103-108, 2010.

[70] J. L. Round and S. K. Mazmanian, "Inducible Foxp3 $3^{+}$regulatory T-cell development by a commensal bacterium of the intestinal microbiota," Proceedings of the National Academy of Sciences of the United States of America, vol. 107, no. 27, pp. 12204-12209, 2010.

[71] S. K. Mazmanian, C. H. Liu, A. O. Tzianabos, and D. L. Kasper, "An immunomodulatory molecule of symbiotic bacteria directs maturation of the host immune system," Cell, vol. 122, no. 1, pp. 107-118, 2005.

[72] V. Farrokhi, R. Nemati, F. C. Nichols et al., "Bacterial lipodipeptide, Lipid 654, is a microbiome-associated biomarker for multiple sclerosis," Clinical \& Translational Immunology, vol. 2, 2013.

[73] M. Kleinewietfeld, A. Manzel, J. Titze et al., "Sodium chloride drives autoimmune disease by the induction of pathogenic $\mathrm{T}_{\mathrm{H}} 17$ cells," Nature, vol. 496, no. 7446, pp. 518-522, 2013.

[74] P. Dowling, W. Husar, J. Menonna, H. Donnenfeld, S. Cook, and M. Sidhu, "Cell death and birth in multiple sclerosis brain," Journal of the Neurological Sciences, vol. 149, no. 1, pp. 1-11, 1997.
[75] K. Schmierer, C. A. M. Wheeler-Kingshott, P. A. Boulby et al., "Diffusion tensor imaging of post mortem multiple sclerosis brain," NeuroImage, vol. 35, no. 2, pp. 467-477, 2007.

[76] A. P. D. Henderson, M. H. Barnett, J. D. E. Parratt, and J. W. Prineas, "Multiple sclerosis: distribution of inflammatory cells in newly forming lesions," Annals of Neurology, vol. 66, no. 6, pp. 739-753, 2009.

[77] M. H. Barnett, J. D. E. Parratt, E.-S. Cho, and J. W. Prineas, "Immunoglobulins and complement in postmortem multiple sclerosis tissue," Annals of Neurology, vol. 65, no. 1, pp. 32-46, 2009.

[78] J. J. Varga, V. Nguyen, D. K. O’Brien, K. Rodgers, R. A. Walker, and S. B. Melville, "Type IV pili-dependent gliding motility in the Gram-positive pathogen Clostridium perfringens and other Clostridia," Molecular Microbiology, vol. 62, no. 3, pp. 680-694, 2006.

[79] H. S. Garmory, N. Chanter, N. P. French, D. Bueschel, J. G. Songer, and R. W. Titball, "Occurrence of Clostridium perfringens $\beta 2$-toxin amongst animals, determined using genotyping and subtyping PCR assays," Epidemiology and Infection, vol. 124, no. 1, pp. 61-67, 2000.

[80] F. A. Uzal, W. R. Kelly, W. E. Morris, J. Bermudez, and M. Baisón, "The pathology of peracute experimental Clostridium perfringens type D enterotoxemia in sheep," Journal of Veterinary Diagnostic Investigation, vol. 16, no. 5, pp. 403-411, 2004.

[81] F. A. Uzal and J. G. Songer, "Diagnosis of Clostridium perfringens intestinal infections in sheep and goats," Journal of Veterinary Diagnostic Investigation, vol. 20, no. 3, pp. 253-265, 2008.

[82] J. P. Garcia, V. Adams, J. Beingesser et al., "Epsilon toxin is essential for the virulence of Clostridium perfringens type D infection in sheep, goats, and Mice," Infection and Immunity, vol. 81, no. 7, pp. 2405-2414, 2013.

[83] T. G. C. Murrell, P. J. O’Donoghue, and T. Ellis, "A review of the sheep-multiple sclerosis connection," Medical Hypotheses, vol. 19, no. 1, pp. 27-39, 1986.

[84] D. B. Diep, K. L. Nelson, T. S. Lawrence, B. R. Sellman, R. K. Tweten, and J. T. Buckley, "Expression and properties of an aerolysin-clostridium sepficum alpha toxin hybrid protein," Molecular Microbiology, vol. 31, no. 3, pp. 785-794, 1999.

[85] J. A. Melton-Witt, L. M. Bentsen, and R. K. Tweten, "Identification of functional domains of Clostridium septicum alpha toxin," Biochemistry, vol. 45, no. 48, pp. 14347-14354, 2006.

[86] K. R. Rumah, J. Linden, V. A. Fischetti, and T. Vartanian, "Isolation of Clostridium perfringens Type B in an individual at first clinical presentation of multiple sclerosis provides clues for environmental triggers of the disease," PLoS ONE, vol. 8, no. 10, Article ID e76359, 2013.

[87] J. Dorca-Arévalo, S. Pauillac, L. Díaz-Hidalgo, M. MartínSatué, M. R. Popoff, and J. Blasi, "Correlation between in vitro cytotoxicity and in vivo lethal activity in mice of epsilon toxin mutants from Clostridium perfringens," PLOS ONE, vol. 9, no. 7, Article ID e102417, 2014.

[88] C. M. Fennessey, J. Sheng, D. H. Rubin, and M. S. McClain, "Oligomerization of Clostridium perfringens epsilon toxin is dependent upon caveolins 1 and 2," PLoS ONE, vol. 7, no. 10, Article ID e46866, 2012.

[89] M. Nagahama and J. Sakurai, "High-affinity binding of Clostridium perfringens epsilon-toxin to rat brain," Infection and Immunity, vol. 60, no. 3, pp. 1237-1240, 1992. 
[90] R. Nagpal, K. Ogata, H. Tsuji et al., "Sensitive quantification of Clostridium perfringens in human feces by quantitative realtime PCR targeting alpha-toxin and enterotoxin genes," $B M C$ Microbiology, vol. 15, 2015.

[91] L. Wioland, J.-L. Dupont, J.-L. Bossu, M. R. Popoff, and B. Poulain, "Attack of the nervous system by clostridium perfringens epsilon toxin: from disease to mode of action on neural cells," Toxicon, vol. 75, pp. 122-135, 2013.

[92] L. Petit, M. Gibert, D. Gillet, C. Laurent-Winter, P. Boquet, and M. R. Popoff, "Clostridium perfringens epsilon-toxin acts on MDCK cells by forming a large membrane complex," Journal of Bacteriology, vol. 179, no. 20, pp. 6480-6487, 1997.

[93] M. S. McClain and T. L. Cover, "Functional analysis of neutralizing antibodies against Clostridium perfringens epsilon-toxin," Infection and Immunity, vol. 75, no. 4, pp. 1785-1793, 2007.

[94] S. Miyata, J. Minami, E. Tamai, O. Matsushita, S. Shimamoto, and A. Okabe, "Clostridium perfringens $\varepsilon$-toxin forms a heptameric pore within the detergent-insoluble microdomains of Madin-Darby canine kidney cells and rat synaptosomes," Journal of Biological Chemistry, vol. 277, no. 42, pp. 3946339468, 2002.

[95] X.-X. Yan, C. J. Porter, S. P. Hardy et al., "Structural and functional analysis of the pore-forming toxin NetB from Clostridium perfringens," mBio, vol. 4, no. 1, Article ID e00019-13, 2013.

[96] S. L. Robertson, J. Li, F. A. Uzal, and B. A. McClane, "Evidence for a prepore stage in the action of Clostridium perfringens epsilon toxin," PLoS ONE, vol. 6, no. 7, Article ID e22053, 2011.

[97] J. Dawson, "The histology of multiple sclerosis," Transactions of the Royal Society of Edinburgh, vol. 50, pp. 517-578, 1916.

[98] R. J. Carman, S. Sayeed, J. Li et al., "Clostridium perfringens toxin genotypes in the feces of healthy North Americans," Anaerobe, vol. 14, no. 2, pp. 102-108, 2008.

[99] N. J. Asha, D. Tompkins, and M. H. Wilcox, "Comparative analysis of prevalence, risk factors, and molecular epidemiology of antibiotic-associated diarrhea due to Clostridium difficile, Clostridium perfringens, and Staphylococcus aureus," Journal of Clinical Microbiology, vol. 44, no. 8, pp. 2785-2791, 2006.

[100] K. M. Maslowski, A. T. Vieira, A. Ng et al., "Regulation of inflammatory responses by gut microbiota and chemoattractant receptor GPR43," Nature, vol. 461, no. 7268, pp. 1282-1286, 2009.

[101] S. Gross, S. T. Gammon, B. L. Moss et al., "Bioluminescence imaging of myeloperoxidase activity in vivo," Nature Medicine, vol. 15, no. 4, pp. 455-461, 2009.

[102] M. A. Kriegel, E. Sefik, J. A. Hill, H.-J. Wu, C. Benoist, and D. Mathis, "Naturally transmitted segmented filamentous bacteria segregate with diabetes protection in nonobese diabetic mice," Proceedings of the National Academy of Sciences of the United States of America, vol. 108, no. 28, pp. 11548-11553, 2011.

[103] K. Machiels, M. Joossens, J. Sabino et al., "A decrease of the butyrate-producing species Roseburia hominis and Faecalibacterium prausnitzii defines dysbiosis in patients with ulcerative colitis," Gut, vol. 63, no. 8, pp. 1275-1283, 2014.

[104] A. Mete, J. Garcia, J. Ortega, M. Lane, S. Scholes, and F. A. Uzal, "Brain lesions associated with Clostridium perfringens type D epsilon toxin in a Holstein heifer calf," Veterinary Pathology, vol. 50, no. 5, pp. 765-768, 2013.

[105] J. Dorca-Arévalo, A. Soler-Jover, M. Gibert, M. R. Popoff, M. Martín-Satué, and J. Blasi, "Binding of $\varepsilon$-toxin from Clostridium perfringens in the nervous system," Veterinary Microbiology, vol. 131, no. 1-2, pp. 14-25, 2008.
[106] E. Lonchamp, J.-L. Dupont, L. Wioland et al., "Clostridium perfringens epsilon toxin targets granule cells in the mouse cerebellum and stimulates glutamate release," PLOS ONE, vol. 5, no. 9, Article ID e13046, 2010.

[107] J. W. Finnie, P. C. Blumbergs, and J. Manavis, "Neuronal damage produced in rat brains by Clostridium perfringens type D epsilon toxin," Journal of Comparative Pathology, vol. 120, no. 4, pp. 415420, 1999.

[108] S. Jhangi, R. Gandhi, B. Glanz, S. Cook, P. Nejad, and D. Ward, "Increased Archaea species and changes with therapy in gut microbiome of multiple sclerosis subjects," Neurology, vol. 82, p. S24.001, 2014.

[109] V. Chiurchiù, M. T. Cencioni, E. Bisicchia et al., "Distinct modulation of human myeloid and plasmacytoid dendritic cells by anandamide in multiple sclerosis," Annals of Neurology, vol. 73, no. 5, pp. 626-636, 2013.

[110] P. G. Miller, M. B. Bonn, C. L. Franklin, A. C. Ericsson, and S. C. McKarns, "TNFR2 deficiency acts in concert with gut microbiota to precipitate spontaneous sex-biased central nervous system demyelinating autoimmune disease," Journal of Immunology, vol. 195, no. 10, pp. 4668-4684, 2015.

[111] M. Messaoudi, R. Lalonde, N. Violle et al., "Assessment of psychotropic-like properties of a probiotic formulation (Lactobacillus helveticus R0052 and Bifidobacterium longum R0175) in rats and human subjects," British Journal of Nutrition, vol. 105, no. 5, pp. 755-764, 2011.

[112] B. Nicol, M. Salou, D.-A. Laplaud, and H. Wekerle, "The autoimmune concept of multiple sclerosis," La Presse Médicale, vol. 44, no. 4, pp. e103-el12, 2015.

[113] K. Hawker, P. O’Connor, M. S. Freedman et al., "Rituximab in patients with primary progressive multiple sclerosis: results of a randomized double-blind placebo-controlled multicenter trial," Annals of Neurology, vol. 66, no. 4, pp. 460-471, 2009.

[114] E. Lécuyer, S. Rakotobe, H. Lengliné-Garnier et al., "Segmented filamentous bacterium uses secondary and tertiary lymphoid tissues to induce gut IgA and specific Thelper 17 cell responses," Immunity, vol. 40, no. 4, pp. 608-620, 2014.

[115] L. A. David, C. F. Maurice, R. N. Carmody et al., "Diet rapidly and reproducibly alters the human gut microbiome," Nature, vol. 505, no. 7484, pp. 559-563, 2014.

[116] M. J. Claesson, I. B. Jeffery, S. Conde et al., "Gut microbiota composition correlates with diet and health in the elderly," Nature, vol. 488, no. 7410, pp. 178-184, 2012.

[117] T. Z. DeSantis, E. L. Brodie, J. P. Moberg, I. X. Zubieta, Y. M. Piceno, and G. L. Andersen, "High-density universal 16S rRNA microarray analysis reveals broader diversity than typical clone library when sampling the environment," Microbial Ecology, vol. 53, no. 3, pp. 371-383, 2007.

[118] I. I. Ivanov, K. Atarashi, N. Manel et al., "Induction of intestinal Th17 cells by segmented filamentous bacteria," Cell, vol. 139, no. 3, pp. 485-498, 2009.

[119] H.-J. Wu, I. I. Ivanov, J. Darce et al., "Gut-residing segmented filamentous bacteria drive autoimmune arthritis via T helper 17 cells," Immunity, vol. 32, no. 6, pp. 815-827, 2010.

[120] K. Atarashi, T. Tanoue, K. Oshima et al., "Treg induction by a rationally selected mixture of Clostridia strains from the human microbiota," Nature, vol. 500, no. 7461, pp. 232-236, 2013.

[121] P. Riccio and R. Rossano, "Nutrition facts in multiple sclerosis," ASN Neuro, vol. 7, no. 1, pp. 1-20, 2015.

[122] H. Yokote, S. Miyake, J. L. Croxford, S. Oki, H. Mizusawa, and T. Yamamura, "NKT cell-dependent amelioration of a mouse 
model of multiple sclerosis by altering gut flora," American Journal of Pathology, vol. 173, no. 6, pp. 1714-1723, 2008.

[123] D. P. Burkitt, "Epidemiology of large bowel disease: the role of fibre," Proceedings of the Nutrition Society, vol. 32, no. 3, pp. 145149, 1973.

[124] C. De Filippo, D. Cavalieri, M. Di Paola et al., "Impact of diet in shaping gut microbiota revealed by a comparative study in children from Europe and rural Africa," Proceedings of the National Academy of Sciences of the United States of America, vol. 107, no. 33, pp. 14691-14696, 2010.

[125] G. Devereux, "The increase in the prevalence of asthma and allergy: food for thought," Nature Reviews Immunology, vol. 6, no. 11, pp. 869-874, 2006.

[126] S. K. Lathrop, S. M. Bloom, S. M. Rao et al., "Peripheral education of the immune system by colonic commensal microbiota," Nature, vol. 478, no. 7368, pp. 250-254, 2011. 


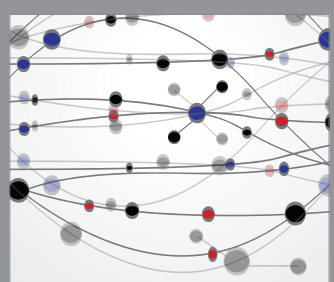

The Scientific World Journal
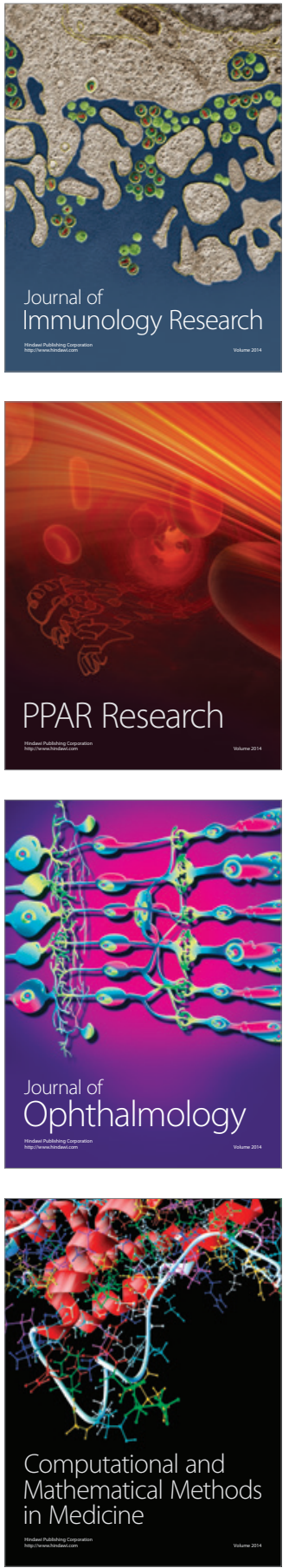

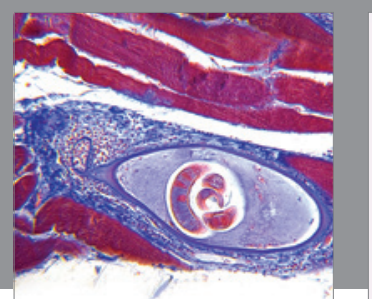

Gastroenterology Research and Practice
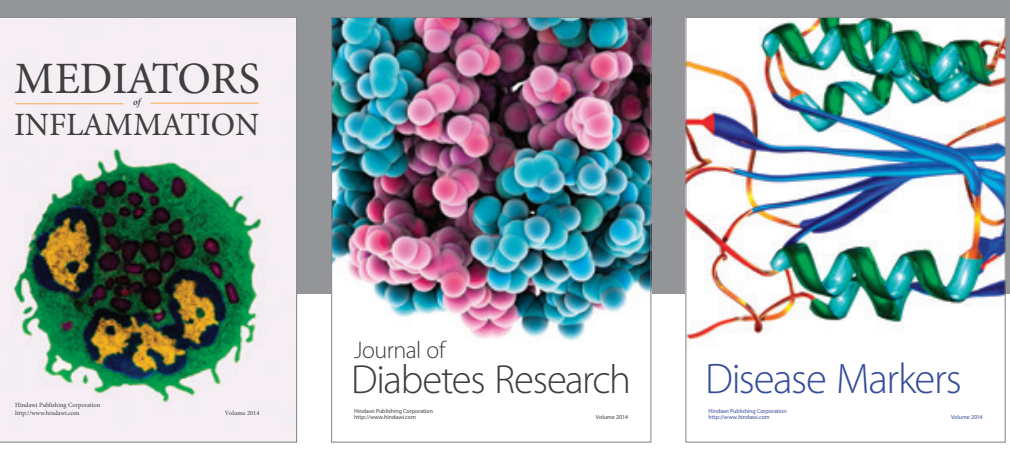

Disease Markers

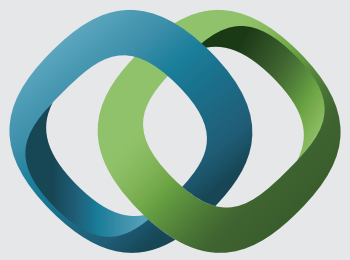

\section{Hindawi}

Submit your manuscripts at

https://www.hindawi.com
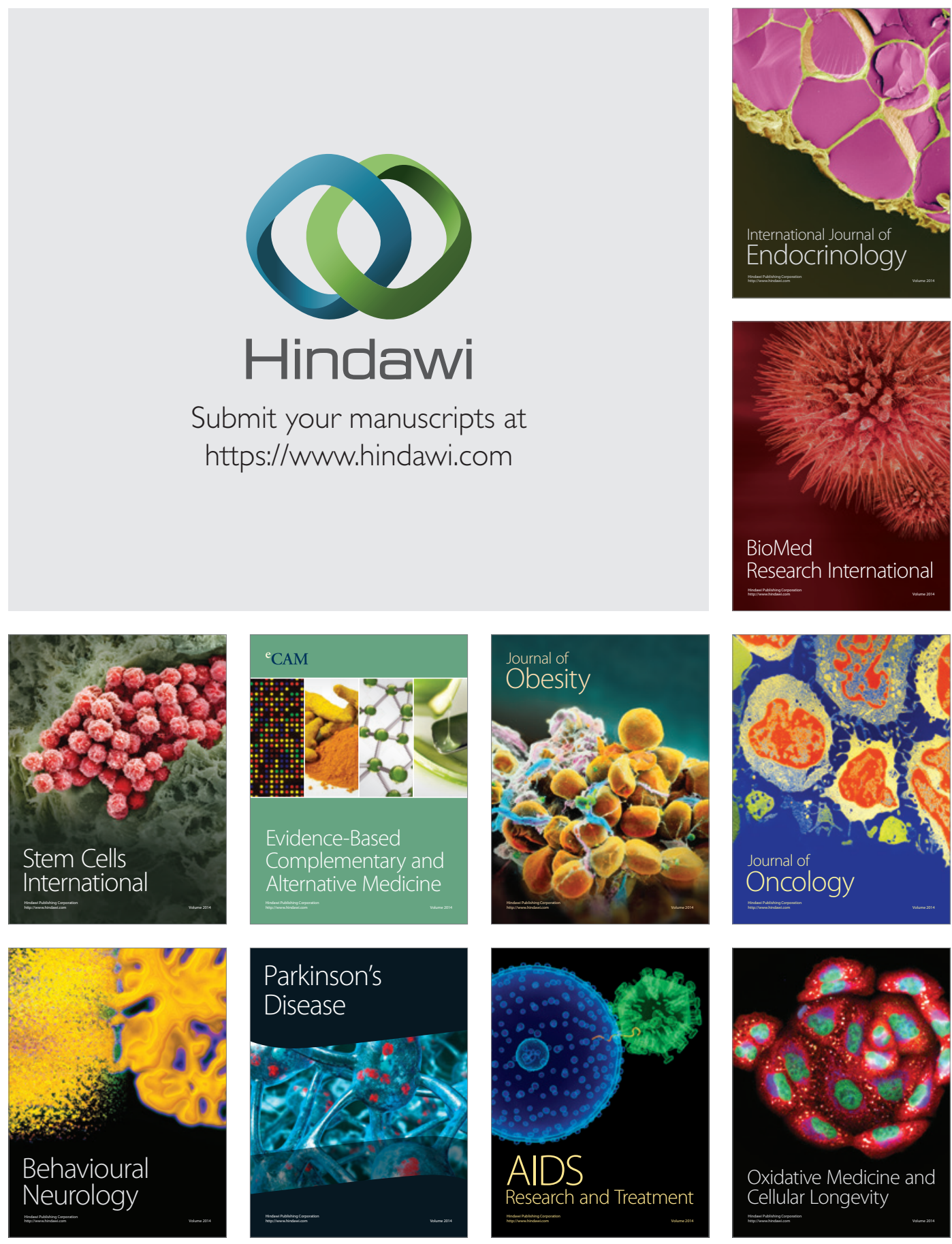